\title{
Old and New Media: On the Construction of Media History
}

Christer Johansson

\section{Abstract}

This chapter investigates how one of the central intermedial relations of media studies, the relation between old and new media, has been conceptualized in media-historical contexts. More specifically, the study discusses how digital media was received, when it was new by the turn of the millennium, by leading media theorists at the time, Jay David Bolter and Richard Grusin and Lev Manovich. A metatheoretical and conceptual analysis is used to uncover the rhetorics and mechanics of media theory and show how old (analogue) and new (digital) media are historically constructed. The analysis of Bolter and Grusin's Remedation and Manovich's The Language of New Media shows how these seminal books, situated in intellectual history, are a mix of traditional theorizing relying on essential definitions of concepts, binary oppositions, and conceptual metaphors such as the container metaphor, and more postmodern strategies such as paradoxical reasoning, a spatial description of history, and conceptual blends of the old and the new. The conclusion discusses how the relation between old and new media should be explored within the field of media theory. The author suggests that we approach media as (metaphorically speaking) hybrids, and focus our intermedial investigations on media-specific phenomena and actual (instead of symbolic) relations between media.

How to cite this book chapter:

Johansson, Christer. "Old and New Media: On the Construction of Media History." In The Power of the In-Between: Intermediality as a Tool for Aesthetic Analysis and Critical Reflection, edited by Sonya Petersson, Christer Johansson, Magdalena Holdar, and Sara Callahan, 375-406. Stockholm: Stockholm University Press, 20I8. DOI: https://doi.org/Io.I6993/baq.o. License: CC-BY. 
One of the central concerns of media theory, emanating from the writings of scholars such as Harold Innis and Marshall McLuhan has, since the early days of the discipline in the r950s and '60s, been the relationship between so-called old media and new media, recently equated with analogue and digital media, respectively. ${ }^{\mathrm{I}}$ Media are thus theorized as a conceptual field consisting of two, more or less, conflicting phenomena-on the one hand, old media, on the other hand, new media. ${ }^{2}$ The conceptual construction of media history, in terms of old and new, is the topic of this text.

More precisely, this chapter has a threefold purpose: I) to discuss how media history has been theorized in intermedial terms, as the interrelations between old and new media; 2) to investigate how digital media were received, when it was new by the turn of the millennium, by leading media theorists at the time; 3) to suggest how the relation between old and new media should be explored within the field of media theory.

More specifically, I will try to uncover the conceptual structures and rhetorical strategies of two well-known studies of new media, two prominent academic books published by the turn of the millennium: Jay David Bolter and Richard Grusin's Remediation: Understanding New Media (1999) and Lev Manovich's The Language of New Media (200I). They share a common subject matter as they try to describe and define the characteristics of "new," digital media, and how these relate to "old" media. The books are also different from each other in that Bolter and Grusin explicitly continue and develop (in a more scientific direction) the media-theoretical tradition of Marshall McLuhan, while Manovich is more influenced by and addresses the tradition of (structuralist) semiotics. These two books are probably among the most-cited works on mediality, still being read and used as

I See Harold A. Innis, Empire and Communications (Toronto and New York: Dundurn Press Limited, 2007 [I950]); Marshall McLuhan, Understanding Media: The Extensions of Man, critical ed. (Corte Madera: Ginko Press, 2003 [1964]). In this chapter, the term "new" digital media refers to media such as the Internet, digital television, interactive multimedia, virtual reality, mobile communication, and video games.

2 See, e.g., Innis, Empire and Communications, 75-105; McLuhan, Understanding Media, 9-35. 
textbooks at universities all over the world. They are thus an important part of the (early) academic reception and construction of "new" digital media and its place in media history. ${ }^{3}$ In addition, the books under scrutiny are, I will argue, in certain important aspects characteristic of how the relations between old and new media are conceptualized in media theory. The theories presented in these studies rely on a number of core concepts designed to enable the writing of media history: remediation, immediacy and hypermediacy (Bolter and Grusin), the language of media (digital media and cinema), interface and database (Manovich). I will demonstrate the intermedial functions of these and other related concepts, that is, how they describe, define, and construct old and new media and how these media are related to each other.

My approach is conceptual and cognitive. Following Mieke Bal, I believe that concepts (thought of as miniature theories, relating to both objects and larger theoretical complexes) should be our focal point of attention when analyzing how theories are constructed and developed, migrated and transformed. ${ }^{4}$ To be able to investigate the concepts of (old and new) media, fundamental to the theories of Bolter and Grusin and Manovich, as well as other important theoretical notions of mediality, I have developed a method of analysis, relying on tools from four different disciplines investigating concepts and conceptual analysis: I) theories of the concept of concept, that explore phenomena such as definitions, basic-level concepts and prototypes; ${ }^{5}$ 2) cognitive theories of mapping and blending,

3 In the introduction to New Media, Old Media: A History and Theory Reader, Wendy Hui Kyong Chun mentions Bolter and Grusin and Manovich as two of the most important contributors to the early critical debate within new media studies. Wendy Hui Kyong Chun and Anna Watkins Fisher with Tomas W. Keenan, eds., New Media, Old Media: A History and Theory Reader, 2nd ed. (New York: Routledge, 2016), 3. On the "newness" and historical context of new media, see Lisa Gitelman and Geoffrey B. Pingree, eds., New Media, I740-I9I (Cambridge: MIT Press, 2003), xi-xxii.

4 Mieke Bal, Travelling Concepts in the Humanities: A Rough Guide (Toronto: University of Toronto Press, 2002), 5-I4.

5 See George Lakoff, Women, Fire, and Dangerous Things: What Categories Reveal About the Mind (Chicago: University of Chicago Press, I987); Gregory L. Murphy, The Big Book of Concepts (Cambridge and London: 
focusing on conceptual metaphors, metonymies, and other varieties of mental projection and integration, implying certain entailments and inferential structures; ${ }^{6} 3$ ) semantic (or conceptual) field theory, that describes different kinds of relations between concepts, such as clusters, doublets, proportional series, and hierarchies; ${ }^{7}$ 4) theories of the transfer of concepts (or "travelling concepts"), that demonstrate how concepts from one (media) discipline are used in, adapted to, and transformed within the confines of another (media) discipline. ${ }^{8}$

It is my contention that these are the important aspects to analyse when investigating and outlining a certain theory and its fundamental concepts. They describe and explain what a concept is (in its literal as well as metaphoric facets) and how the concept of concept has been approached in different traditions, how concepts relate to other concepts and to different scientific contexts. I will explain and demonstrate these and other metatheoretical notions and how they contribute to our understanding of different concepts of mediality, as the conceptual analysis of the two studies targeted in this chapter progresses.

First, I will analyse the concept of medium (including new media), the theory of remediation as a conceptual field of media history and three conceptual metaphors underpinning Bolter and Grusin's theory of intermedial relations; second, after a short

MIT Press, 2002); Eleanor Rosch and Barbara B. Lloyd, Cognition and Categorization (Hillsdale: Erlbaum, I978), 27-48.

6 See George Lakoff and Mark Johnson, Metaphors We Live By (Chicago and London: The University of Chicago Press, 2003 [I980]); George Lakoff and Mark Johnson, Philosophy in the Flesh: The Embodied Mind and its Challenge to Western Thought (New York: Basic Books, I999); Gilles Fauconnier and Mark Turner, The Way We Think: Conceptual Blending and the Mind's Hidden Complexities (New York: Basic Books, 2002).

7 See David Bordwell, Making Meaning: Inference and Rhetoric in the Interpretation of Cinema (Cambridge: Harvard University Press, I989); Alan D. Cruse, Lexical Semantics (Cambridge: Cambridge University Press, I986); Eve Feder Kittay, Metaphor: Its Cognitive Force and Linguistic Structure (Oxford: Clarendon, I990).

${ }^{8}$ See Bal, Travelling Concepts; Birgit Neumann, Ansgar Nünning, and Mirjam Horn, eds., Travelling Concepts for the Study of Culture (Berlin: Walter de Gruyter \& Co, 20I2). 
comparison between the two books, I will show how Manovich investigates relations, analogies and similarities, between old and new media, by way of different kinds of conceptual transfers, described in terms of conceptual mapping and blending. Whenever the analysis touches upon what I consider to be a question or pattern of a more general scope, of importance for media theory and related disciplines, I will address it. Lastly, in a conclusion, I will try to situate the two studies in intellectual history, summarize and evaluate how the constellation of concepts in the analysed theories function to delineate the interrelation between old and new media and construct media history, and finally suggest some alternative approaches.

\section{Bolter and Grusin's Theory of Remedation}

\section{The Concept of (New Digital) Medium}

The core concept of Remediation is the concept of remediation, closely related to the concepts of medium, mediation, and new media. ${ }^{9}$ These four terms, at times, seem to constitute a small cluster, a conceptual field of synonyms, that is, four different but equivalent descriptions of the same concept. ${ }^{10}$ Bolter and Grusin offer the following definition of "medium":

a medium is that which remediates. It is that which appropriates the techniques, forms, and social significance of other media and attempts to rival or refashion them in the name of the real. A medium in our culture can never operate in isolation, because it must enter into relationships of respect and rivalry with other media. ${ }^{\mathrm{II}}$

9 On the relationship between intermediality and remediation, see Irina O. Rajewsky, "Intermediality, Intertextuality, and Remediation: A Literary Perspective on Intermediality," Intermediality: History and Theory of the Arts, Literature and Technologies, no. 6 (2005): 43-64.

ro A cluster is a conceptual field in which items have a semantic overlap and a low degree of contrastiveness. Bordwell, Making Meaning, I I 5-I I6; Cruse, Lexical Semantics, 265-270; compare Kittay, Metaphor, 237-242.

I Jay David Bolter and Richard Grusin, Remediation: Understanding New Media (Cambridge: MIT Press, I999), 65. 
Consequently, a medium is, by definition, that which remediates. In a similar fashion, the authors argue that all "mediation is remediation." " 22 And the same is true of new digital media, which has as a defining characteristic the "representation of one medium in another" (for example a website representing moving images), that is, "remediation." I3 The synchronic interrelations between media, old and new ones, in specific media objects and cultural networks at large, and the diachronic developments of media history are built into the concept of medium. This way of thinking is deeply rooted in the North American media-theoretical tradition and more specifically, Bolter and Grusin admit, incited by McLuhan, who contends that the "content" of any medium is always another medium, "one medium is itself incorporated or represented in another medium"; the content of writing is speech, the written word is the content of print, print is the content of the telegraph, and so on. ${ }^{\mathrm{I}}$ Furthermore, this figure of thought is obviously akin to the academic discourses of intertextuality (all signs and texts are related to other signs and texts) and intermediality (all media are mixed media). ${ }^{15}$ The defining characteristic of medium and mediation is thus, according to Bolter and Grusin, a relational (in distinction to an intrinsic), even intermedial, property of sorts. ${ }^{16}$ At the same time, this definition of medium appears to be an essential definition, remediation being a necessary and perhaps even sufficient condition for medium, mediation, and, above all,

I2 Bolter and Grusin, Remediation, 55.

13 Bolter and Grusin, Remediation, 45.

${ }^{14}$ Bolter and Grusin, Remediation 45; cf. 66; see McLuhan, Understanding Media, I7-35.

I5 See Ferdinand de Saussure, Cours de linguistique générale (Lausanne: Payot, I916), I 55-169; Charles S. Peirce, "Logics as Semiotic: The Theory of Signs," in Semiotics: An Introductory Anthology, ed. Robert E. Innis (Bloomington: Indiana University Press, I985), I-23; Gérard Genette, Palimpsests: Literature in the Second Degree (Lincoln: University of Nebraska Press, I997), I-7; W. J. T. Mitchell, "There Are No Visual Media," in MediaArtHistories, ed. Oliver Grau (Cambridge: MIT Press, 2007), 395-408, and Julia Kristeva's famous coinage of the term intertextuality, referred to in Peter Gillgren's chapter.

I6 Cf. Noël Carroll, "Fiction, Non-fiction, and the Film of Presumptive Assertion: A Conceptual Analysis," in Film Theory and Philosophy, eds. Richard Allen and Murray Smith (Oxford: Clarendon Press, I997), I79. 
new digital media. ${ }^{17}$ However, Bolter and Grusin take great pains to avoid the fallacy of media essentialism. ${ }^{18}$ The authors stress that in arguing that all mediation is remediation they do not mean that remediation is "the irreducible essence of either digital media or mediation generally," but rather that at our historical moment, remediation is the predominant convention at work in establishing the identity of new digital media. With a different but related move, Bolter and Grusin argue that the remediation of new digital media is both what is "unique to digital worlds" and what denies the possibility of that uniqueness. ${ }^{19}$ The definition of new media as remediation is thus formulated as a paradox. Finally, remediation is described as "a spectrum of different ways in which digital media remediate their predecessors." ${ }^{20}$ The tension between new and old media varies from zero (a website faithfully rendering an old movie) to an aggressive will to transform and absorb (old television clips distorted in digital video art), and remediation operates in both directions. ${ }^{2 \mathrm{I}}$ Remediation, the defining characteristic of media, mediation, and new media, is not only a relational property, but a graded series of possibilities, depending on the shifting interrelations between old and new media. ${ }^{22}$

To avoid media essentialism, Bolter and Grusin employ three different strategies to make their central concept of (new) digital media fuzzier and bring it closer to the notions of family resemblance and culture dependent (proto)typicality: historical contextualisation, the use of paradox and the graded series. ${ }^{23}$ Their

${ }^{17}$ On definitions and essences, necessity and sufficiency, see Murphy, Big Book on Concepts, I 2; cf. Lakoff and Johnson, Philosophy in the Flesh, 379-382.

${ }^{18}$ On media essentialism, see, e.g., Lisa Gitelman, Always Already New: Media, History, and the Data of Culture (Cambridge: MIT Press, 2006), 8 -io.

19 Bolter and Grusin, Remediation, 50.

20 Bolter and Grusin, Remediation, 45.

21 Bolter and Grusin, Remediation, 27, 45-48.

22 Conceptual fields can be structured hierarchically, either in branching or nonbranching forms. See Bordwell, Making Meaning, I 20-I 24; Cruse, Lexical Semantics, I I 2-I I 8, I36-I96.

${ }_{23}$ On the fuzziness of concepts, family resemblance and prototypes, see Murphy, The Big Book on Concepts, I6, I 7, 20-22; Ludwig Wittgenstein, Philosophical Investigations (Oxford: Blackwell, I953), paragraphs 65, 
definition of medium and description of the relations between new digital media and older forms of media hover between essence and deliberate fuzziness. Perhaps we could conclude that the concept of medium, in the theory of Bolter and Grusin, grows out of an, at times, unresolved tension (or double logic) between media essentialism (the old way to define concepts and describe phenomena) and non-essentialist strategies (the new approach to concepts and definitions), a tension corresponding to their understanding of the charged interrelations between old and new media.

Remediation, and the Relations between Old and New Media, as a Conceptual Field

It is not surprising then that the paradoxical notion of remediation, thought of as a conceptual field, is structured by a doublet or binary opposition. ${ }^{24}$ Already in the introduction to Remedation, Bolter and Grusin discuss our culture's “contradictory imperatives for immediacy and hypermediacy" and what they call "a double logic of remediation." ${ }^{25}$ Bolter and Grusin's theory is thus structured by this fundamental binary opposition, the contradictory relation between two different media phenomena characterising the interrelations between old and new media: immediacy (the putative erasure of the sign vehicles of media, for example realistic cinema) and hypermediacy (the multiplying of and self-referential highlighting of media, for example montage film). All media, old and new, grow out of these opposing modes, they are the driving forces behind remediation and the development of media history.

To construct a theory about cultural objects, of some sort, and their history by way of binary oppositions is probably one of the most common and traditional methods of theorising in Western thought. ${ }^{26}$ More specifically, Bolter and Grusin's double logic of

67; Rosch, Cognition and Categorization, 36; cf. Lakoff, Women, Fire, and Dangerous Things, 5-57.

${ }^{24}$ See Bordwell, Making Meaning, II7-II8; Cruse, Lexical Semantics, I97264; Kittay, Metaphor, 20-22; cf. Daniel Chandler, Semiotics: The Basics (London: Routledge, 2002), IOI-II 8.

25 Bolter and Grusin, Remediation, 5. Italics in the original.

${ }^{6}$ See, e.g., Bordwell, Making Meaning, I I7-I I8, I22; Chandler, Semiotics, IOI-I I 8; John Bell, Oppositions and Paradoxes: Philosophical Perplexities in 
remediation is akin to, or perhaps even inspired by, age-old aesthetic doublets such as mimesis versus diegesis, showing versus telling, and realism versus self-reflexivity or defamiliarisation. ${ }^{27}$ The opposition between immediacy and hypermediacy is developed, by the authors, into a series of doublets, a propositional series, organized as parallel clusters of associated terms: ${ }^{28}$

immediacy, transparence, looking through, gaze, product, unified, window, erasure, effacement, reality, experience, presence, content, reproduction, autonomy

hypermediacy, opacity, looking at, glance, process, heterogeneous, windowed, sign, mediated, medium, surface, agency, material, representation, multiplicity

To organize a theory as a series of doublets forming parallel clusters is, again, a very common strategy in many areas of the human sciences, especially in media theory. ${ }^{29}$ We find it not only in McLuhan, who to a large extent structures his discourse as series of connected doublets (old and new media, industrial age and electronic age, hot and cold media, high and low definition,

Science and Mathematics (Peterborough: Broadview Press, 2016); Jonathan Culler, On Deconstruction: Theory and Criticism after Structuralism (Ithaca: Cornell University Press, I982), 85-226; Jacques Derrida, Positions (Chicago: University of Chicago Press, I982), 4I; Roman Jakobson and Moris Halle, Fundamentals of Language, and rev. ed. (The Hague: Mouton, I97I); Irena Rima Makaryk, ed., Encyclopedia of Contemporary Literary Theory: Approaches, Scholars, Terms (Toronto: University of Toronto Press, I993), 5 II.

27 See, e.g., The Living Handbook of Narratology, accessed June 9, 2017, http://wikis.sub.uni-hamburg.de/lhn/index.php/Diegesis_-_Mimesis; Winfried Nöth and Nina Bishara, eds., Self-reference in the Media (Berlin: Mouton de Gruyter, 2007), 3-30; Marie-Laure Ryan, Narrative as Virtual Reality: Immersion and Interactivity in Literature and Electronic Media (Baltimore: Johns Hopkins University Press, 200I), I-2I.

${ }_{28}$ See Bordwell, Making Meaning, II8-I20; Cruse, Lexical Semantics, II $8-135$.

29 In their book Social Semiotics, under the heading "Saussure's rubbish bin," Robert Hodge and Gunther Kress uncover the binarism of Saussure's semiology and build their social semiotics of the conceptual opposites that Saussure excludes from his theory. Robert Hodge and Gunther Kress, Social Semiotics (Cambridge: Polity, I988), I 5-I 8; cf. Bordwell, Making Meaning, I I 7-I20, I24-I 26. 
and so on), $3^{\circ}$ but also for example, and perhaps more surprisingly, in the texts of a postmodern and posthumanist scholar such as Katherine Hayles, who in her study How We Think: Digital Media and Contemporary Technogenesis (2012), discusses the discourses, methods and institutions of so-called digital humanities (and its relation to print-based equivalents) in terms of doublets and tensions: digital humanities versus print-based humanities, quantitative/qualitative, text-based/time-based, machine/brain, algorithmic analysis/hermeneutic close reading, linear temporal causality/ spatialized grids, narrative/database, argumentation/embodiment, and so on. ${ }^{31}$

Bolter and Grusin are of course aware of the tradition and problems of binarism. Consequently, they have the ambition to deconstruct, or at least qualify or soften, the binarism of their media historiography. In order to accomplish this, Bolter and Grusin employ the strategy of paradoxical reasoning. The authors describe the conceptual field of remediation, and the relationship between immediacy and hypermediacy, in paradoxical terms; the so-called double logic of remediation seems to be a paradoxical one: "Our culture wants both to multiply its media and to erase all traces of mediation: ideally, it wants to erase its media in the very act of multiplying them." ${ }^{2}$ This major paradox is the result of a series of synthesising strategies and minor paradoxes. The history of media and remediation is defined as an interplay between immediacy and hypermediacy, new digital media is said to oscillate between transparency and opacity, and the seemingly contradictory logics are "mutually dependent." ${ }_{33}$ The opposites seem to include each other; hypermedia strive for immediacy, the quest for immediacy leads to hypermediacy:

30 McLuhan, Understanding Media, 39-50, 73-8 I, 2 I 5-22I.

${ }^{3}$ Katherine N. Hayles, How We Think: Digital Media and Contemporary Technogenesis (Chicago and London: The University of Chicago Press, 2OI2), 23-54. To be fair, Hayles is conscious and critical of the binarism of the digital humanities discourse and approaches the field with a deconstructive ambition. Still, her discussion is permeated by binary thinking.

32 Bolter and Grusin, Remediation, 5.

33 Bolter and Grusin, Remediation, I7, 6; cf. 84 . 
Although each medium promises to reform its predecessors by offering a more immediate or authentic experience, the promise of reform inevitably leads us to become aware of the new medium as a medium. Thus, immediacy leads to hypermediacy. 34

Bolter and Grusin's argument is that immediacy and hypermediacy are somehow causally connected, the one leads to the other through the process of remediation, and drives media history.

Moreover, transparent media and hypermedia are opposite expressions of the same ambition to achieve the real and the authentic. ${ }^{35}$ Bolter and Grusin try to pinpoint common features that immediacy and hypermediacy share, and thus to find some overarching category that might include both of them:

Hypermedia and transparent media are opposite manifestations of the same desire: the desire to get past the limits of representation and to achieve the real. [...] Transparent digital applications seek to get to the real by bravely denying the fact of mediation; digital hypermedia seek the real by multiplying mediation so as to create a feeling of fullness, a satiety of experience, which can be taken as reality. ${ }^{36}$

The excess of digital hypermedia becomes, according to the authors, an "authentic experience," not in the sense that it corresponds to an external reality, but because it "does not feel compelled to refer to anything beyond itself." ${ }_{77}$ Consequently, both immediacy and hypermediacy lead to the authentic, all new media remediate the real..$^{8}$ This move is realized by widening the extension of the concepts of the real and the authentic to cover more than they initially seem to cover, not only contents but forms and sign vehicles as well. ${ }^{39}$

34 Bolter and Grusin, Remediation, I7; cf. 37, 54.

35 Bolter and Grusin, Remediation, 53, 59, 70.

36 Bolter and Grusin, Remediation, 53.

37 Bolter and Grusin, Remediation, 53-54; cf. 58, 59.

${ }_{38}$ Bolter and Grusin, Remediation, 59.

39 The widening of the extension of the real and the authentic is a restructuring of the conceptual field of remediation by way of categorisation by branching hierarchy; see Bordwell, Making Meaning, I2O-I 24; Cruse, Lexical Semantics, I I 2-I I 8. 
To summarize, Bolter and Grusin construct their theory of media history, and the relations between old and new media, as a binary system consisting of parallel clusters of oppositions, and then try to undermine this system by way of paradoxical reasoning. The theory of remediation and new media is thus characterized by the tension between conceptual essentialism and fuzziness, on the one hand, and the parallel tension between binarism and the paradoxical, on the other.

\section{The Conceptual Metaphors of Remediation and Media History}

According to cognitive theorists George Lakoff and Mark Johnson most of our thinking and all our abstract categories are structured by conceptual metaphors (or metaphoric concepts), which means "understanding and experiencing one kind of thing in terms of another." ${ }^{\circ}$ This observation is valid for scientific theories as well as everyday concepts..$^{4}$ Bolter and Grusin make extensive, intermedial use of conceptual metaphors. To describe the relations between old and new media, and the processes of remediation and media history, they employ three central conceptual metaphors, two ontological ones describing media as such and a spatial metaphor structuring the temporality of media history: the conduit or container metaphor, personification and the metaphor of resonance.

One of the most powerful metaphors in Remediation is also one of the most discussed conceptual metaphors, the so-called conduit or container metaphor, common in descriptions of communication and representation..$^{42}$ I have already touched upon McLuhans importance for the concept of remediation. His influence is also discernable when it comes to the metaphoric concept of containment. Bolter and Grusin write:

${ }^{\circ \circ}$ Lakoff and Johnson, Metaphors We Live By, 5, IO-I2, 246; Lakoff and Johnson, Philosophy in the Flesh, I28.

${ }^{4}$ See Lakoff and Johnson, Philosophy in the Flesh, 335-548.

${ }^{42}$ The container metaphor is a kind of entity/substance metaphor which allows us to understand our experiences "in terms of objects or substances of a uniform kind.” Lakoff and Johnson, Metaphors We Live By, 25. 
On the opening page of Understanding Media (I964), Marshall McLuhan remarked that "the 'content' of any medium is always another medium. The content of writing is speech, just as the written word is the content of print, and print is the content of the telegraph." As his problematic examples suggest, McLuhan was not thinking of simple repurposing, but perhaps of a more complex kind of borrowing in which one medium is itself incorporated or represented in another medium. Dutch painters incorporated maps, globes, inscriptions, letters, and mirrors in their works. ${ }^{43}$

Following and revising McLuhan, Bolter and Grusin contend that the "content" of any medium is another medium; computer games remediate, that is, contain the medium of film, and so on. ${ }^{44}$ In a similar fashion, one of the poles on the axis of remediation, the extreme where an older medium is represented in digital form without any real tension, is described by way of the container metaphor. In cases such as websites that offer texts and pictures for download, the digital medium is not set in opposition to other media like painting, photography, or printing; instead, the computer is functioning as a new means of gaining access to these older media, "as if the content of the older media could simply be poured into the new one." ${ }^{45}$ Media, old and new, are thus metaphorically treated as objects and substances and are related to each other, both synchronically and diachronically, as container and contained.

As I have already touched on, the conduit/container metaphor is one of the most fundamental traditional conceptual metaphors in scientific as well as non-scientific descriptions of communication and representation. As Michael Reddy demonstrates in a seminal article, the default conceptual metaphor in English describing lingustic communication is the conduit metaphor. The speaker puts ideas (objects) into words (containers) and sends them (along a conduit) to a hearer who takes the idea/objects out of the word/ containers. ${ }^{46}$ Bolter and Grusin thus reuse (or remediate) one of

43 Bolter and Grusin, Remediation, 45.

44 Bolter and Grusin, Remediation, 45.

45 Bolter and Grusin, Remediation, 45-46; cf. 48, 68.

${ }^{46}$ Michael Reddy, "The Conduit Metaphor," in Metaphor and Thought, ed. A. Ortony (Cambridge: Cambridge University Press, I979), 284-324; Lakoff and Johnson, Metaphors We Live By, 29-32. An influential scientific 
the most important traditional cultural and scientific metaphors for communication and representation to describe the relations between old and new media. This conception of remediation entails that media have "meanings" in themselves (an old medium such as cinema is, for example, present in a new medium like computer games), independent of any context, a figure of thought that downplays the contextual aspects of mediality.

As is evident in the quotation above, where Bolter and Grusin discuss McLuhan, the concept of remediation and the relationship between media are also formulated in terms of personification (media acting as agents);47 remediation is, for example, described as a kind of "borrowing." " 48 However, the most important personifications revolve around a never-ending power struggle between media. The spectrum of remediation is said to be dependent on "the degree of perceived competition or rivalry between the new media and the old media." 49 The interrelations between old and new media (such as cinema and computer games) are frequently described in terms of action, honour, response, acknowledgement, reaffirmation, challenge, aggression, attack, invocation, and remake. Old and new media are brought to life and made into the participants in a media-historical drama about the power over culture.

manifestation of this conceptual metaphor is linguist Loius Hjelmslev's sign model, a development of Saussure's signifier/signified dichotomy, which in Hjelmslev's terminology becomes a distinction between expression plane and content plane on the one hand, and between form and substance, on the other; there is thus a form of the content and a form of the expression, a substance of the content and a substance of the expression. Louis Hjelmslev, Prolegomena to a Theory of Language, rev. English ed. (Madison: University of Wisconsin Press, I96I [I943]), 47-60. Hjelmslev's sign model has been transmediated, i.e., applied to other and different media than natural languages, by, e.g., narratologist Seymour Chatman, investigating literary, cinematic and potentially all kinds of narratives. Seymour Chatman, Story and Discourse: Narrative Structure in Fiction and Film (Ithaca and London: Cornell University Press, I978), 22-27.

47 On personification, see Lakoff and Johnson, Metaphors We Live By, 33 .

${ }^{8}$ Bolter and Grusin, Remediation, 45.

49 Bolter and Grusin, Remediation, 45; cf. 5, I4-I 5, 46, 55, 86. 
This theoretical strategy is not only common in media theory and history, ${ }^{\circ}$ but also of central importance in the more ideologically tainted branch of intermediality studies, most notably represented by W. J. T. Mitchell. In the chapter "What is an image" in his Iconology (I986), a classic in the field of intermediality studies, Mitchell describes the relations between media, in this case pictorial and linguistic signs, and the development of cultural history by way of personification and the metaphor of power struggle:

The dialectic of word and image seems to be a constant in the fabric of signs that a culture weaves around itself. [...] The history of culture is in part the story of a protracted struggle for dominance between pictorial and linguistic signs, each claiming for itself certain proprietary rights on a "nature" to which only it has access. ${ }^{51}$

Mitchell does not want to "heal the split" between words and images, but to see what "interests and powers it serves." ${ }^{2}$ The figurative struggle between personified media is thus one of the fundamental metaphors of research on media history.

To describe the relations between media from different historical periods Bolter and Grusin refer to Michel Foucalt's notion of genealogy, but choose another metaphor when stating that "we too are looking for historical affiliations or resonances and not for origins." ${ }_{33}$ To avoid the supposed misleading notions of origins and chronology, Bolter and Grusin introduce the concept of

5० Cf. Gitelman Always Already New, 8-1o.

${ }_{5}$ W. J. T. Mitchell, Iconology: Image, Text, Ideology (Chicago: Chicago University Press, I986), 43.

${ }_{52}$ Mitchell, Iconology, 44. In a later work by Mitchell, What Do Pictures Want?, the personification of media and pictorial representations is presented as a conscious method of media analysis. Mitchell's poetics of pictures is a study of "'the lives of images', from the ancient idols and fetishes to contemporary technical images and artificial life-forms, including cyborgs and clones." The question to ask of pictures from the standpoint of poetics is not just what "they mean or do but what they want-what claim they make upon us, and how we are to respond." W. J. T. Mitchell, What Do Pictures Want?: The Lives and Loves of Images (Chicago: University of Chicago Press, 2005), xv.

53 Bolter and Grusin, Remediation, 2I, note I. 
"historical resonances (to Renaissance painting, nineteenth-century photography, twentieth-century film, and so on)" that will be offered to "help explain the contemporary situation." 54 To describe the relations between new digital media and older forms of media, "resonances," a physics and acoustics concept, is used, entailing that different media in different historical circumstances can be thought of as connected physical objects or systems, in continuous space, affected by the same forces. This non-chronological, antinarrative and antiteleological approach to media history has become a staple in recent media studies disciplines such as media archaeology (see 392-397). ${ }^{55}$

In conclusion, the relations between old and new media are thus described, by Bolter and Grusin, as containers containing objects, as interactions between living beings, and as physical strata connected by acoustic phenomena in a continuous space. One might wonder how these metaphors go together in the theory of remediation. One answer is that they don't. Most theories are probably built on conflicting, or inconsistent, conceptual metaphors. Various metaphorical configurations of a concept serve different purposes by highlighting different aspects of a concept (in this case remediation). ${ }^{56}$ But there may still be metaphorical coherence. The three metaphors of remediation, two ontological metaphors and a time metaphor, all imply and highlight an essentialist understanding of media. ${ }^{57}$ Media are conceived of as agents, forces and objects with essences that can affect and be incorporated in other media with other essences. To complicate things, the "resonances" metaphor also has a non-essentialist and postmodern quality, since it challenges the traditional notion of media history as a chronological narrative.

54 Bolter and Grusin, Remediation, 2 I; cf. 34-35.

55 See, e.g., Erkki Huhtamo and Jussi Parikka, "Introduction: An Archaeology of Media Archaeology," in Media Archaeology: Approaches, Applications, and Implications, eds. Erkki Huhtamo and Jussi Parikka (Berkeley: University of Carlifornia Press, 20II), I-2I. Huhtamo and Parikka contend that Bolter and Grusin's endeavor has “affinities with the ways media archaeologists draw parallels between seemingly incompatible phenomena." Huhtamo and Parikka, Media Archaeology, 5.

${ }_{56}^{6}$ Lakoff and Johnson, Metaphors We Live By, 96, I00-105.

57 Cf. Gitelman Always Already New, 8-Io. 


\section{Manovich and the Language of New Media}

Manovich's study has some fundamental features in common with the media theory of Bolter and Grusin. His investigation of new media and their relation to old media, is structured by similar binary systems, forming clusters of associated concepts:

viewer - user, perceiving - acting, transparent - opaque, representation - control, illusion - interactivity, immersion - direct address

Manovich describes new media as remediations of old media, refers explicitly to Bolter and Grusin,,$^{58}$ and uses various metaphors of containment (cinema is "poured" into the computer), ${ }^{59}$ personification and media rivalry. The computer screen is described as a "battle field" for a number of opposites, such as window and control, depth and surface, transparency and opaqueness. ${ }^{60}$ Human culture is, in a similar vein, represented as a struggle between database and narrative:

As a cultural form, the database represents the world as a list of items, and it refuses to order this list. In contrast, a narrative creates a cause-and-effect trajectory of seemingly unordered items (events). Therefore, database and narrative are natural enemies. Competing for the same territory of human culture, each claims an exclusive right to make meaning out of the world. ${ }^{61}$

There seems to be a common scientific "language" for the study of the "language" of new media, current at the time (by the turn of the millennium), shared by Bolter and Grusin and Manovich. Interestingly enough the two studies rely on contrasting metaphors for the temporality of media history. Manovich's view of media history is more traditional than the "spatial" one, represented by the metaphor of resonance, presented by Bolter and Grusin. The historical relations of and between old and new media are, in Manovich's description, much more of a plot-driven,

${ }^{5}$ Lev Manovich, The Language of New Media (Cambridge: MIT Press, 200I), 7I, 79, 83, 84 .

59 Manovich, Language of New Media, 86.

${ }_{60}$ Manovich, Language of New Media, 90-9 I, 2 I 6.

${ }^{61}$ Manovich, Language of New Media, 225; cf. 89, 228, 23 I, 234. 
even teleological, narrative. There is chronology, movement, progression, causality, and shifts. Manovich discusses, for example, the "general evolution of all media types toward increased modularity, and the particular evolution of the moving image in the same direction [...]." ${ }^{62}$ Two different temporal metaphors, with different inferential logics, structure the two studies. Bolter and Grusin delineate media history as simultaneity in a unified space (a version of the Time as Space metaphor), Manovich represents media history as a vehicle moving through space, towards a destination (an instance of the Time's Landscape metaphor). ${ }^{63}$

So, Manovich presents a more traditional view of media history, at least as regards his choice of temporal metaphor. However, one of Manovich's most important theoretical strategies is more in line with the resonance metaphor used by Bolter and Grusin, that is, his (media-archaeological) tendency to observe and/or create relations, analogies and similarities, between old and new media, by way of different kinds of conceptual transfers. Following cognitive theory, I will discuss this fundamental theoretical approach in terms of conceptual mapping and blending.

\section{Travelling Concepts and the Construction of Media History}

Manovich's study sets in motion different varieties of conceptual transfer (or travelling concepts), that is, the transfer of concepts across the borders of media and media disciplines: ${ }^{64}$ transmediation, conceptual remediation, anachronistic mapping, and conceptual blending.

The introduction to Manovich's book clearly demonstrates some of the author's most important transmedial strategies. Manovich uses Dziga Vertov's avant-garde classic Man with a

${ }_{62}$ Manovich, Language of New Media, I40; cf. xvii, I33, I48.

63 See Lakoff and Johnson, Philosophy in the Flesh, I45-I46, I60.

${ }^{64}$ Conceptual transfer (or travelling concepts, a term coined by Mieke Bal) demonstrates how concepts from one (media) discipline are beeing used in, adapted to and transformed within the confines of another (media) discipline. See Bal, Travelling Concepts, 3-55; Neumann, Nünning, and Horn, eds. Travelling Concepts for the Study of Culture, I-22. 
Movie Camera as "our guide to the language of new media." ${ }_{5}$ The prologue consists of a series of stills from the film. Each still is accompanied by a quote from the text, summarizing a particular principle of new media:

A hundred years after cinema's birth, cinematic ways of seeing the world, of structuring time, of narrating a story, of linking one experience to the next, have become the basic means by which computer users access and interact with all cultural data. In this respect, the computer fulfills the promise of cinema as a visual Esperanto-a goal that preoccupied many film artists and critics in the I920s, from Griffith to Vertov.

And in contrast to cinema, where most "users" are able to "understand" cinematic language but not "speak" it (i.e., make films), all computer users can "speak" the language of the interface. ${ }^{66}$

These passages communicate a complex combination of conceptual transfers. Most importantly, Manovich transmediates the concept of language, mapping it onto both (old) cinema and new media, comparing the logics behind the developments of "film language" and "the language of new media." By transmediation I mean the use of a concept, rooted in a certain media-studies discipline, as the vehicle for an overarching and generalized notion, supposedly valid for all or most kinds of media. ${ }^{67}$ The transmediation of "language" is one of the most well-known, most productive, and most devastating scientific mappings in the history of the humanities. I am of course thinking of the structuralist paradigm, initiated by Ferdinand de Saussure, treating all kinds of meaningful signs (literature, film, theatre, fashion, advertising, and so on) as languages of sorts. ${ }^{68}$ Manovich is highly aware of this, and his use of the language metaphor is a conscious move:

${ }_{65}$ Manovich, Language of New Media, xiv.

${ }^{66}$ Manovich, Language of New Media, xv, 78-79; cf. xxvi-xxvii.

${ }^{67}$ On the concept of transmediality, see, e.g., Lars Elleström, Media Transformation: The Transfer of Media Characteristics Among Media (Basingstoke: Palgrave Macmillan, 20I4); Jan-Noël Thon, Transmedial Narratology and Contemporary Media Culture (Lincoln: University of Nebraska Press, 2016).

${ }^{68}$ de Saussure, Cours de linguistique générale, 23-35, 97-II3. See also, 
In putting the word language into the title of the book, I do not want to suggest that we need to return to the structuralist phase of semiotics in understanding new media. However, given that most studies of new media and cyberculture focus on their sociological, economic, and political dimensions, it was important for me to use the word language to signal the different focus of the work: the emergent conventions, recurrent design patterns, and key forms of new media. ${ }^{69}$

Manovich thus takes pains to distance himself from the "structuralist phase" of semiotics. Still, the metaphoric projection of "language" onto cinema and new media is a transmedial semiotic project akin to the structuralist one, and a prerequisite for Manovich's comparisons between old and new media. Manovich uses "language" as "an umbrella term" to refer to "various conventions" used by designers of new media objects and representations to "organize data" and "structure the user's experience." 70 The metaphoric use of "language" thus highlights the conventional, formal, and logical qualities of the media in question, while downplaying iconic and indexical media aspects, as well as context-dependent features of meaning and mediality. ${ }^{7 \mathrm{~T}}$ The mapping of "language" onto cinema and new media also paves the way for the mapping of traditional (structuralist) semiotic concepts, such as codes (or conventions) for communication, syntagm (sequential relations between elements) and paradigm (mutually exclusive choices), originally designed, by scholars such as Roman Jakobson and Louis Hjelmslev, to describe and explain the workings of natural languages and literature, onto other and different media..$^{72}$ Consequently, the computer interface is discussed in terms of codes:

e.g., John Sturrock, Structuralism, 2nd ed. (Oxford: Blackwell Publishing, 2003), 25-47, 74-97.

69 Manovich, Language of New Media, I 2.

70 Manovich, Language of New Media, 7.

${ }^{71}$ Iconicity (meaning production by way of similarity) and indexicality (meaning production by way of contiguity) are of course central concepts in the semiotic tradition emanating from Charles Sanders Peirce, see, e.g., Peirce "Logics as Semiotics," 8-I9.

72 See, e.g., Roman Jakobson, "Language in Relation to Other Communication Systems," in Selected Writings, vol. 2 (The Hague: Mouton, I97I), 
In semiotic terms, the computer interface acts as a code that carries cultural messages in a variety of media. When you use the Internet, everything you access-texts, music, video, navigable spaces-passes through the interface of the browser and then, in turn, the interface of the OS. In cultural communication, a code is rarely simply a neutral transport mechanism; usually it affects the message transmitted with its help. [...] Most modern cultural theories rely on these notions [...]. For instance, according to the Whorf-Sapir hypothesis [...] human thinking is determined by the code of natural language; the speakers of different natural languages perceive and think about the world differently. [...] when we think about the case of the human-computer interface, applying a "strong" version of this idea makes sense. ${ }^{73}$

The interface is a semiotic code, the vehicle of cultural messages, and it provides (the Whorf-Sapir hypothesis being refashioned and mapped) its own model of the world, its own bias. To reiterate, Manovich's theoretical strategy for the construction of media history is an abundantly clear instance of conceptual transmediation: concepts from one area of mediality and media studies (language, linguistics/structuralist semiotics) being mapped onto other and all kinds of media objects and communicative devices. This transmediation, recycling the old structuralism project, is the basis for a series of more radical conceptual transfers structuring Manovich's study.

As indicated in the quoted passages above, Manovich observes and investigates affinities between the historical developments of cinema and new media. This analogy between media evolutions is detected, demonstrated, or perhaps created by way of a combination of two kinds of conceptual transfer I would like to call conceptual remediation and anachronistic mapping. Early in his book Manovich states that "the theory and history of cinema serve as the key conceptual lens though [sic!] which I look at new media." ${ }_{74}$ Manovich thus employs film theory (and film

697-7ıо; Hjelmslev, Prolegomena, 73-76; Chandler, Semiotics, 83-84, I $47, \mathrm{I} 48$.

73 Manovich, Language of New Media, 64; cf. 65, 229-233.

${ }^{74}$ Manovich, Language of New Media, 9; cf. I I, 287. 
history) as a means of analysing new media. ${ }^{75}$ Consequently, new media are described and defined by concepts transferred from cinema studies, such as screen, montage, mobile camera and point of view, and the subject of realism in $3-\mathrm{D}$ computer animation is treated with reference to the arguments advanced in film theory about cinematic realism. ${ }^{76}$ This is an instance of conceptual remediation (thus myself transferring and transforming Bolter and Grusin's concept in a metatheoretical context): concepts specifically developed, within a certain discipline, to describe, define and analyse a certain medium and its characteristics, are mapped onto a different (usually younger) medium, within the confines of a new discipline.

The second strategy, anachronistic mapping, travels in the opposite direction, from new media and media disciplines to old ones. Manovich discusses Vertov's Man with a Movie Camera in terms of computer technology and science. Vertov is described as a major "database filmmaker" and his famous movie is proclaimed the most important example of a "database imagination in modern media art." 77 The concepts of interface and database are mapped onto Vertovs's work:

In his research on what can be called "kino-eye interface," Vertov systematically tried different ways to overcome what he thought were the limits of human vision. [...] Man with a Movie Camera is not only a database of city life in the I920s, a database of film techniques, and a database of new operations of visual epistemology, but also a database of new interface operations that together aim to go beyond simple human navigation through physical space. ${ }^{78}$

The compound expression "kino-eye interface" is a brilliant manifestation of the strategy of anachronistic mapping, that is, a transfer of concepts from the discipline of computer studies, developed for the analysis of new digital media, to the analysis of (the older medium of) film.

75 Manovich, Language of New Media, I I.

${ }^{76}$ Manovich, Language of New Media, 9, 78, 84, I 84-1 87, 320-326.

77 Manovich, Language of New Media, xxiv, 239.

${ }^{78}$ Manovich, Language of New Media, xxx; cf. 62. 
The combination of anachronistic mapping, projecting concepts from computer science onto cinema, and conceptual remediation, mapping concepts from cinema studies onto new media, generates something akin to a so-called conceptual blend: relations and properties from different domains of mediality (cinema and cinema studies, new digital media and computer studies), and scenarios (cinema as new media, new media as cinema) are imaginatively integrated, resulting in apparent analogies between media. ${ }^{79}$ This method is an important part of the media-archaeological enterprise (with Manovich as one of its forerunners), focusing on historical ruptures and a discontinuous media history analysed by way of unexpected analogies. ${ }^{8 \circ}$

To summarize, Manovich uses different methods for conceptual transfer and mapping to communicate his view of media history and the interrelations of old and new media. Travels and mappings move in all directions and the overriding objective seems to be the detection, demonstration, or perhaps creation of analogies between media and historical contexts. This strategy is akin to the resonance metaphor set in motion by Bolter and Grusin and closely related to the media-archaeological project mentioned above.

\section{Conclusions}

\section{Old and New Media in the Digital Age}

The scientific reception, or construction, of digital media and media history, as it is manifested in the works of Bolter and Grusin and Manovich by the turn of the millennium, is formulated as an intermedial relation, the relation between old analogue media and new digital media. The concept of medium is defined in relational and intermedial terms as well: all media must be understood through their relations to other media,

79 The theory of conceptual blends is an extension of cognitive metaphor theory. See Fauconnier and Turner, The Way We Think, 26I, 263.

8० See Huhtamo and Parikka, Media Archaeology, I3; cf. 3, 4, 6, 7, 9-ı, I 5 . 
mediation is always remediation. The overarching conceptual field, the doublet of old and new, is systematically analysed and broken down into multiple doublets. Remediation, the driving force of media history, defined by Bolter and Grusin and adopted by Manovich, is structured by the fundamental binary opposition between immediacy and hypermediacy. This opposition is developed into series of doublets, organized as parallel clusters of associated terms. The relations between old and new media, and the processes of remediation, are also, in both Bolter and Grusin and Manovich, structured by way of two fundamental ontological conceptual metaphors, the conduit (or container) metaphor and personification. Media are, on the one hand, related to each other as container and contained (the computer contains cinema), on the other hand personified and described as agents or forces involved in an endless struggle for power and control (the narrative and the database).

These three related strategies, mediation (essentially) defined as remediation, (re)mediation structured as a conceptual field consisting of series of binaries, and media connections described by way of the ontological metaphors of containment and personification should, I think, be viewed as traditional conceptual devices deployed to control the chaotic and all-encompassing domain of new, digital mediality. Media are thought of as oppositions, objects or forces characterized by discernible essences. The same is true of Manovich's transmediation of language, turning both old analogue media and new digital media into codes and conventions. The unfamiliar is made familiar by the use of traditional analytic and theoretical methods and models.

There is, however, an opposite tendency in both works under scrutiny, a postmodern (for lack of a better term) ambition to undermine and deconstruct traditional notions of concept definition, representation, and history. Bolter and Grusin try to reach beyond the traditional logics of the concept of medium, binarism, and chronological media history by a consistent use of paradoxical reasoning and spatialized analysis. Manovich achieves a similar effect by way of an analytical method consisting of a multidirectional conceptual transfer (a combination of conceptual remediation and anachronistic mapping), ultimately resulting in 
the creation of conceptual blends of old and new media. These postmodern strategies intentionally make things fuzzier and more complex, to meet the requirements of the new and unfamiliar, with a blurring of traditional analytic clarity as one of their side effects.

So, situated in intellectual history, these two closely related constructions of media history and conceptualizations of digital media are characterized by a tension between the use of traditional scientific approaches and postmodern strategies defying traditional scientific logic, a tension corresponding to the tension between old analogue and new digital media. Let us leave this tension unresolved since it is, I believe, as close as we can get to the non-essentialist essences of these important books.

Remediation and The Language of New Media are still relevant as they manifest some of the most important tendencies and productive ideas in both past and contemporary media theory: media and mediation defined as the interrelations between media, the metaphoric understanding of the interrelations between old and new media in terms of objects and containers, animate beings and power struggle, the use of clusters of binaries to describe the conceptual fields of media, and the deployment of strategies like anachronistic mapping or a spatialization of temporality to write a non-chronological and antiteleological media history. To end this chapter I will try to challenge some of these ideas, both traditional and postmodern, by once more returning to Bolter and Grusin's and Manovich's books. Let us downplay some of the central notions and highlight some less central ones, pose some questions and hint at some alternative solutions. ${ }^{8 \mathrm{I}}$

${ }^{8 \mathrm{I}}$ Two recent attempts to discuss and reformulate central notions in media theory (the concept of content, media and meaning, binarism, media, and agency) are W. J. T. Mitchell and Mark B. N. Hansen, eds., Critical Terms for Media Studies (Chicago: The University of Chicago Press, 20I0), vii-xxii and John Durham Peters, The Marvelous Clouds: Toward a Philosophy of Elemental Media (Chicago: The University of Chicago Press, 2015), I3-52. 
Media as Hybrids, Media Specificity, and Historical Literalness

One of the less central conceptual metaphors in Remediaton seems to me much more important and productive than metaphors such as media as containers and the struggle between media conceived of as agents or the metaphor of resonance. Bolter and Grusin write:

Futhermore, media technologies constitute networks or hybrids that can be expressed in physical, social, aesthetic, and economic terms. Introducing a new media technology does not mean simply inventing new hardware and software, but rather fashioning (or refashioning) such a network..$^{82}$

Interestingly enough, the same metaphor can be found in Manovich's book: "The language of cultural interfaces is a hybrid. It is a strange, often awkward mix between the conventions of traditional cultural forms and the conventions of HCI [...]." ${ }_{3}$ I suggest that we focus on the hybrid metaphor, MEDIA and MEDIA HISTORY ARE HYBRIDS, and highlight it (while at the same time downplaying the metaphors mentioned above). ${ }^{84}$ Media "are" hybrids, that is, physical, social, aesthetic, and economic phenomena and relations, and to describe them, and the interrelations between old and new media, accurately, we must take all these aspects into consideration. This is not, by any means, an original suggestion; MEDIA ARE HYBRIDS is part of Mitchell's argumentation against media purity in "There Are No Visual Media," and already set in motion by McLuhan. ${ }^{85}$ It is also closely related to current theories on media as multimodal and heteromedial conglomerates. ${ }^{86}$ Even if not an original suggestion, I find the metaphor and its entailments and inferential structures (indicating

82 Bolter and Grusin, Remediation, I7.

${ }_{3}$ Manovich, Language of New Media, 9I.

${ }^{84} \mathrm{I}$ also suggest that we avoid the network metaphor since it is so closely related to the all-present and dominant internet.

${ }_{5}$ Mitchell, “There Are No Visual Media,” 396, 398; McLuhan, Understanding Media, 7I-8I.

86 See, e.g., Elleström, Media Transformation, 36-45; Jørgen Bruhn, The Intermediality of Narrative Literature: Medialities Matter (London: Palgrave Macmillan, 2016), I 5, 42. 
the multifacetedness and context of the phenomena) useful: it says that media and its interrelations are something complex and complicated that we must investigate very carefully and in detail. The MEDIA ARE HYBRIDS metaphor thus fits our experiences of media and the relations between old and new media better than alternative metaphors. ${ }^{87}$ Instead of, metaphorically, turning media and media history into objects, containers, and persons playing different roles in a binary power struggle, I think we should view them as the multifaceted, strange, and awkward phenomena that they are.

Another thing I would like to promote is the notion of medium specificity and the necessary transformation of travelling concepts and avoidance of anachronistic mappings and analogies. Manovich discusses the concept of "operation," a new concept for new media: "it would be a mistake to reduce the concept of an operation to a 'tool' or 'medium.' In fact, one of the assumptions underlying this book is that these traditional concepts do not work very well in relation to new media, and thus we need new concepts like 'interface' and 'operation." " 88 New media, new environments, and new historical circumstances call for new and different concepts. Moreover, following the same logic, concepts transferred from the discourse of one medium to another medium, from one discipline to another discipline, must not only be transferred and applied, they must also be transformed to do their job in the new scientific environment.

Finally, I want to argue for historical literalness (the methodological and literal counterpart of the "media are hybrid" metaphor), for lack of a better term. Bolter and Grusin are aware of the problem of personification and the figurative wars of media. They admit that when writing something like "'digital media are challenging the status of television and film' we are asking readers to treat this as shorthand." The longer version would include individuals, groups, and institutions that create and use digital media as improved forms of television and film. ${ }^{89}$ In the introduction

${ }_{87}$ See Lakoff and Johnson, Metaphors We Live By, I39-I 46.

${ }^{88}$ Manovich, Language of New Media, I 2 I.

${ }^{89}$ Bolter and Grusin, Remediation, 78; cf. criticism in Gitelman, Always Already New, 9. 
to her seminal study, Always Already New: Media, History, and the Data of Culture (2006), media historian Lisa Gitelman criticizes this theoretical tendency to essentialize and naturalize media by way of treating them as if they were "unchanging, 'immutable objects with given, self-defining properties,"” as well as the parallel tendency to describe media as "self-acting agents of their own history." $9 \circ$ According to Gitelman media are very particular sites for very particular, importantly social as well as historically and culturally specific experiences of meaning. ${ }^{9 \mathrm{I}}$ And what we should investigate, Gitelman seems to recommend, is the real and literal agency of mediality: authors, designers, engineers, entrepreneurs, programmers, investors, owners, or audiences. ${ }^{92}$ Conceptual metaphors, analogies, and mappings of different kinds are, not only unavoidable but also highly useful when employed in a systematic way, but let us avoid misleading shorthand and distorting conceptual fields and mappings, whenever we can, and describe and explore actual interrelations between old and new media (mediated by real agents and actions) instead of symbolic ones.

\section{References}

Bal, Mieke. Travelling Concepts in the Humanities: A Rough Guide. Toronto: University of Toronto Press, 2002.

Bell, John L. Oppositions and Paradoxes: Philosophical Perplexities in Science and Mathematics. Peterborough: Broadview Press, 2016.

Bolter, Jay David, and Richard Grusin. Remediation: Understanding New Media. Cambridge: MIT Press, I999.

Bordwell, David. Making Meaning: Inference and Rhetoric in the Interpretation of Cinema. Cambridge: Harvard University Press, I989.

Bruhn, Jørgen. The Intermediality of Narrative Literature: Medialities Matter. London: Palgrave Macmillan, 2016.

\footnotetext{
$9 \circ$ Gitelman, Always Already New, 8, 9.

91 Gitelman, Always Already New, 8.

$9^{2}$ Gitelman, Always Already New, 9-Io.
} 
Carroll, Noël. "Fiction, Non-fiction, and the Film of Presumptive Assertion: A Conceptual Analysis." In Film Theory and Philosophy, edited by Richard Allen and Murray Smith, I73-202. Oxford: Clarendon Press, I997.

Chandler, Daniel. Semiotics: The Basics. London: Routledge, 2002.

Chatman, Seymour. Story and Discourse: Narrative Structure in Fiction and Film. Ithaca and London: Cornell University Press, I978.

Chun, Wendy Hui Kyong, and Anna Watkins Fisher, with Tomas W. Keenan, eds. New Media, Old Media: A History and Theory Reader. 2nd ed. New York: Routledge, 2016.

Curse, Alan D. Lexical Semantics. Cambridge: Cambridge University Press, I986.

Culler, Jonathan. On Deconstruction: Theory and Criticism after Structuralism. Ithaca: Cornell University Press, I982.

Derrida, Jacques. Positions. Translation and annotation by Alan Bass. Chicago: University of Chicago Press, I982 [1972].

Elleström, Lars. Media Transformation: The Transfer of Media Characteristics Among Media. Basingstoke: Palgrave Macmillian, $20 I 4$.

Fauconnier, Gilles, and Mark Turner. The Way We Think: Conceptual Blending and the Mind's Hidden Complexities. New York: Basic Books, 2002.

Genette, Gérard. Palimpsests: Literature in the Second Degree. Lincoln: University of Nebraska Press, 1997.

Gitelman, Lisa. Always Already New: Media, History, and the Data of Culture. Cambridge: MIT Press, 2006.

Gitelman, Lisa, and Geoffrey B. Pingree, eds. New Media, I740-I9I 5. Cambridge: MIT Press, 2003.

Hayles, Katherine N. How We Think: Digital Media and Contemporary Technogenesis. Chicago and London: The University of Chicago Press, 20I 2.

Hjelmslev, Louis. Prolegomena to a Theory of Language. Rev. English ed. Madison: University of Wisconsin Press, I96 I [I943]. 
Hodge, Robert, and Gunther Kress. Social Semiotics. Cambridge: Polity, I988.

Huhtamo, Erkki, and Jussi Parikka. "Introduction: An Archaeology of Media Archaeology." In Media Archaeology: Approaches, Applications, and Implications, edited by Erkki Huhtamo and Jussi Parikka, I-22. Berkeley: University of California Press, $2 O I I$.

Innis, Harold A. Empire and Communications. Toronto and New York: Dundurn Press Limited, 2007 [1950].

Jakobson, Roman. "Language in Relation to Other Communication Systems.” In Selected Writings, vol. 2, 697-708. The Hague: Mouton, I97I.

Jakobson, Roman, and Moris Halle. Fundamentals of Language, 2nd revised edition. The Hague: Mouton, I97 I [1956].

Kittay, Eve Feder. Metaphor: Its Cognitive Force and Linguistic Structure. Oxford: Clarendon, I990.

Lakoff, George. Women, Fire, and Dangerous Things: What Categories Reveal About the Mind. Chicago: University of Chicago Press, I987.

Lakoff, George, and Mark Johnson. Philosophy in the Flesh: The Embodied Mind and its Challenge to Western Thought. New York: Basic Books, I999.

Lakoff, George, and Mark Johnson. Metaphors We Live By. Chicago and London: The University of Chicago Press, 2003 [1980].

The Living Handbook of Narratology. Accessed June 9, 20I7. http:// wikis.sub.uni-hamburg.de/lhn/index.php/Diegesis_-_Mimesis.

Makaryk, Irena Rima, ed. Encyclopedia of Contemporary Literary Theory: Approaches, Scholars, Terms. Toronto: University of Toronto Press, I993.

Manovich, Lev. The Language of New Media. Cambridge: MIT Press, 200I.

McLuhan, Marshall. Understanding Media: The Extensions of Man. Critical ed. Corte Madera: Ginko Press, 2003 [1964]. 
Mitchell, W. J. T. Iconology: Image, Text, Ideology. Chicago: University of Chicago Press, 1986.

Mitchell, W. J. T. What Do Pictures Want?: The Lives and Loves of Images. Chicago: University of Chicago Press, 2005.

Mitchell, W. J. T. “There Are No Visual Media.” In MediaArtHistories, edited by Oliver Grau, 395-408. Cambridge: MIT Press, 2007.

Mitchell, W. J. T., and Mark B. N. Hansen, eds. Critical Terms for Media Studies. Chicago: The University of Chicago Press, 20 Iо.

Murphy, Gregory L. The Big Book of Concepts. Cambridge and London: MIT Press, 2002.

Neumann, Birgit, Ansgar Nünning, and Mirjam Horn, eds. Travelling Concepts for the Study of Culture. Berlin: Walter de Gruyter \& Co., $20 \mathrm{I} 2$.

Nöth, Winfried, and Nina Bishara, eds. Self-reference in the Media. Berlin: Mouton de Gruyter, 2007.

Peirce, Charles S. "Logics as Semiotic: The Theory of Signs." In Semiotics: An Introductory Anthology, edited by Robert E. Innis, I-23. Bloomington: Indiana University Press, I985.

Peters, John Durham. The Marvelous Clouds: Toward a Philosophy of Elemental Media. Chicago: The University of Chicago Press, 2015 .

Rajewsky, Irina O. "Intermediality, Intertextuality, and Remediation: A Literary Perspective on Intermediality." Intermediality: History and Theory of the Arts, Literature and Technologies, no. 6 (2005): 43-64.

Reddy, Michael. “The Conduit Metaphor.” In Metaphor and Thought, edited by A. Ortony, 284-324. Cambridge: Cambridge University Press, I979.

Rosch, Eleanor, and Barbara B. Lloyd. Cognition and Categorization. Hillsdale: Erlbaum, I978.

Ryan, Marie-Laure. Narrative as Virtual Reality: Immersion and Interactivity in Literature and Electronic Media. Baltimore: Johns Hopkins University Press, 200I. 
Saussure, Ferdinand de. Cours de linguistique générale. Lausanne: Payot, I9I6.

Sturrock, John. Structuralism. 2nd ed. Oxford: Blackwell Publishing, 2003.

Thon, Jan-Noël. Transmedial Narratology and Contemporary Media Culture. Lincoln: University of Nebraska Press, 20 I 6.

Wittgenstein, Ludwig. Philosophical Investigations. Oxford: Blackwell, I953. 